\title{
Faba bean (Vicia faba L.) seeds darken rapidly and phenolic content falls when stored at higher temperature, moisture and light intensity
}

\author{
S.M. Nasar-Abbas ${ }^{\text {a,b,c* }}$, K.H.M. Siddique ${ }^{\mathrm{c}, \mathrm{d}}$, J.A. Plummer ${ }^{\mathrm{a}, \mathrm{d}}$ P.F. White ${ }^{\mathrm{e}}$, D. Harris ${ }^{\mathrm{f}}$, K. \\ Dods $^{f}$ and M. D'Antuono ${ }^{\mathrm{e}}$
}

${ }^{a}$ School of Plant Biology, Faculty of Natural and Agricultural Sciences, The University of Western Australia, 35 Stirling Hwy, Crawley WA 6009, Australia

${ }^{b}$ School of Public Health, Curtin University of Technology, PO Box U1987, Perth 6845, Australia

${ }^{c}$ Centre for Legumes in Mediterranean Agriculture (CLIMA), Faculty of Natural and Agricultural Sciences, The University of Western Australia, 35 Stirling Hwy, Crawley WA 6009, Australia

${ }^{d}$ Institute of Agriculture, The University of Western Australia, 35 Stirling Hwy, Crawley WA 6009, Australia

${ }^{e}$ Department of Agriculture and Food, Western Australia, 3 Baron-Hay Court, South Perth WA 6151, Australia

${ }^{f}$ Chemistry Centre WA, 125 Hay St, East Perth WA 6004, Australia

*Corresponding author; e-mail: S.Abbas@curtin.edu.au

\section{Abstract}

Faba beans cv. Fiesta with seed moisture content (SMC) modified to 8, 10, 12 and 14 \% were packed in polyethylene lined aluminium foil bags and stored at 5, 15, 20, 25, 30, 37, 45, 50 or $60{ }^{\circ} \mathrm{C}\left( \pm 2^{\circ} \mathrm{C}\right)$ for one year. Samples were analysed for moisture content and seed coat (testa) colour over the storage period using a chroma meter. A continuous increase in $L^{*}$ and $b^{*}$ values was found in all samples with the passage of time whereas $a^{*}$ values first increased and then decreased in samples stored at relatively high temperatures $\left(\geq 37^{\circ} \mathrm{C}\right)$. The initial beige testa colour changed to light brown, dark reddish brown or almost black depending on storage conditions. The higher the temperature and SMC the faster the rate of change in colour $\left(\Delta \mathrm{E}^{*} \mathrm{ab}\right.$ values). Seeds with $8 \%$ SMC had more stable testa colour compared to seeds with higher SMC. Exposure to artificial light (350 $\mu \mathrm{mol} \mathrm{m}^{-2} \mathrm{~s}^{-1}$ ) substantially accelerated the colour darkening. Cotyledon stored at $37 \pm 2{ }^{\circ} \mathrm{C}$ also darkened with the storage time. A loss in total free phenolics, total tannins and proanthocyanidins was found with increased darkness of testa and cotyledons during storage.

Keywords: Pulse; Seed coat; Cotyledons; Colour darkening; Phenolics 


\section{Introduction}

Colour of seed testa is important for the marketing of faba bean for human consumption. Across different faba bean varieties, seed testa colour ranges from white to purple but the preferred colour has variously been described as beige, light tan or buff (AGWEST, 1998). Light brown or beige is also the most common (91\% of accessions at ICARDA) seed coat colour in faba bean at harvest (Robertson \& El-Sherbeeny, 1991), however it is not stable and darkens during storage. Seed coat colour may change to medium brown, dark brown and even chocolate brown depending upon the storage conditions and duration. Postharvest colour darkening of faba bean reduces its value and market opportunity. Consumers and processors are reluctant to purchase darkened seed because colour is considered as an index of quality or freshness and consumers associate dark colour with old seed (Hughes \& Sandsted, 1975). Furthermore, during heat processing or canning the immersion liquid or broth changes to a dark muddy colour (Dickinson, Knight \& Rees, 1957). Thus dark seeds are unacceptable to the unprocessed as well as the canning market.

Storage conditions strongly influence the stability of postharvest seed colour in many types of beans. In other legumes there is some evidence that temperature, relative humidity $(\mathrm{RH})$, seed moisture content (SMC) and light are the main factors that affect the stability of seed colour during storage (Hughes et al., 1975; Nordstorm \& Sistrunk, 1977; Nozzolillo \& De Bezada, 1984; Park \& Maga, 1999). High temperature $\left(24{ }^{\circ} \mathrm{C}\right)$ and high $\mathrm{RH} \ngtr 80 \%$ ) accelerated darkening in kidney beans (Phaseolus vulgaris L.) while beans stored at low temperature (1 ${ }^{\circ} \mathrm{C}$ ) and RH (30\%) retained their original colour for one year (Hughes and Sandsted 1975). Storage of chickpea (Cicer arietinum L.) at $33-35{ }^{\circ} \mathrm{C}$ and $75 \%$ relative humidity for 160 days caused postharvest testa colour darkening which was reflected by decrease in Hunter 'L' value and increase in total colour differencAF) 
Rodelo, Gomez-Garza \& Milan-Carrillo, 2000). Lentil (Lens culinaris Medic.) seeds exposed to moderately high temperature $\left(20\right.$ and $\left.30^{\circ} \mathrm{C}\right)$ at high $\mathrm{RH}(100 \%)$ turned brown in 3 weeks or less while at cool temperature $\left(5^{\circ} \mathrm{C}\right)$ with same $\mathrm{RH}(100 \%)$ browning did not occur before 5 weeks (Nordstorm \& Sistrunk, 1979; Nozzolillo et al., 1984). Similarly little change in postharvest seed coat colour occurred in Rwandan dry beans (Phaseolus vulgaris) stored at 4 ${ }^{\circ} \mathrm{C}$ for 24 months (Edmister, Breene \& Serugendo, 1990). Light red kidney beans also retained their original colour for one year when stored at $1{ }^{\circ} \mathrm{C}$ (Gunes \& Lee, 1997). Even at moderately low temperature $\left(10^{\circ} \mathrm{C}\right)$ darkening was slow in adzuki beans (Vigna angularis) (Yousif, Kato \& Deeth, 2003).

This study aimed to assess the rate and intensity of postharvest colour darkening of faba bean using a range of storage conditions and to find the correlation of phenolic contents with postharvest colour darkening. Once known, optimum storage condition could be used to minimise darkening and hence maintain seed colour for extended periods.

\section{Materials and methods}

\subsection{Plant Material}

Faba beans (Vicia faba L.), cv. Fiesta, were grown at Borden (11.26 E longitude, 34.07 S latitude), Western Australia as part of the normal trial activities of the National Faba Bean Improvement Program. Beans were harvested in December 2003 and kept at $5{ }^{\circ} \mathrm{C}$ in the dark until used for experiments in February 2004. Good colour (beige/buff) and healthy seeds (free from insect damage, visible viral or fungal attack or broken testa) were individually selected. The average seed weight was 73.2 g per 100 seeds. 
2.2. Effect of storage temperatures, seed moisture content and light on postharvest testa colour

The moisture contents of seeds were modified to 8.4, 10.3, 11.8 and $13.6 \mathrm{~g} / 100 \mathrm{~g}$ (hereafter referred to as 8, 10, 12 and 14\% respectively) by dehydration over silica gel or rehydration in a 75\% RH chamber (Wexler, 1997). Initial and final seed moisture contents were determined by applying a standard air-oven method (AACC, 2000). Seed samples (3 x 25 g) were placed in polyethylene lined aluminium foil bags $(10 \mathrm{x} 10 \mathrm{~cm})$ and sealed using an impulse heat sealer. Bags were placed in plastic containers and stored at 5, 15, 20, 25, 30, 37, 45, 50 or 60 ${ }^{\circ} \mathrm{C}\left( \pm 2{ }^{\circ} \mathrm{C}\right)$ in controlled temperature storage rooms or hot air ovens. Minimum-maximum thermometers were placed in the storage boxes to monitor temperature changes during storage. A part of the seeds with $12 \%$ SMC were placed in bags $(10 \times 10 \mathrm{~cm})$ prepared using a transparent polyvinyl chloride (PVC) sheet and sealed as above. The bags were placed in a cool room at $20 \pm 2{ }^{\circ} \mathrm{C}$ under artificial light (GroLux, T8, SYLVANIA, Germany) with photosynthetic photon flux of $350 \mu \mathrm{mol} \mathrm{m} \mathrm{m}^{-2}$ (Quantum Meter, QMSW, Apogee Instruments, USA). To measure the light intensity received by seeds the meter detector was covered with the same transparent PVC sheet used for the packaging samples.

Seeds were removed and left at room temperature $\left(25 \pm 2{ }^{\circ} \mathrm{C}\right)$ for one hour and then analysed for moisture content (weight gain/loss of the bag) and seed coat (testa) colour at $0,0.5,1,2,3$, 4, 6, 8, 10 and 12 months of storage. Colour was measured and then they were immediately resealed and returned to the respective storage conditions.

\subsection{Effect of storage temperature on the kernel (cotyledon) colour}

Faba bean samples with 12\% SMC were dehulled using a mechanical dehuller equipped with an aspirator (S. K. Engineering, India). The kernels (3 x 25 g) were placed in polyethylene 
104 lined aluminium foil bags and sealed as above. Samples were stored at $37 \pm 2{ }^{\circ} \mathrm{C}$ and analysed

105 for moisture content and colour changes at 0, 0.5, 1, 2, 3, 4, 6, 8, 10 and 12 months storage 106 interval.

107

108

109

110

111

112

113

114

115

116

117

118

119

120

121

122

123

124

125

126

127

\subsection{Colour measurement}

Seed coat colour was determined using a Minolta CR-310 chroma meter (Minolta, Japan) using the Granular-Materials Attachment CR-A50. Data were collected for $L^{*}, a^{*}$ and $b^{*}$ values. $L^{*}$ value represents lightness, $a^{*}$ value greenness and redness and $b^{*}$ value blueness and yellowness. A white porcelain plate $\left(L^{*}=97.75, a^{*}=-0.08\right.$, and $\left.b^{*}=+1.77\right)$ supplied with the instrument was used for calibration.

In order to ascertain the practical significance of changes in objective measures of faba bean testa colour during storage, Colour Difference Index $\left(\Delta \mathrm{E}^{*}{ }_{\mathrm{ab}}\right)$ was calculated from $L^{*}, a^{*}$ and $b^{*}$ colour coordinates by the Eq. I (Anonymous, 1991):

$\Delta \mathrm{E}_{\mathrm{ab}}^{*}=\left[\left(\Delta L^{*}\right)^{2}+\left(\Delta a^{*}\right)^{2}+\left(\Delta b^{*}\right)^{2}\right]^{1 / 2}$ Eq. I

Where $\Delta L^{*}=L_{1}^{*}-L_{2}^{*}, \Delta a^{*}=a^{*}{ }_{1}-a_{2}^{*}$ and $\Delta b^{*}=b^{*}{ }_{1}-b_{2}^{*}$

Initial $L^{*}, a^{*}$ and $b^{*}$ values (subscript by 1 ) and values at each storage interval (subscript by 2) were used to develop $\Delta \mathrm{E}^{*}$ ab values and this was used to compare postharvest colour changes in the samples.

\subsection{Postharvest colour darkening acceptability level}

Faba beans having a range of colour darkening attained after storage for one year at different temperatures were photographed by a professional photographer using a digital camera (Nikon D100; 6Mp, Japan). The photograph (Fig. 1) was sent to local and foreign grain handlers, exporters/importers and faba bean breeders/scientists and their comments were sought on the 
maximum acceptable level of postharvest colour darkening for local and international marketing. According to their comments the samples with $12 \%$ SMC stored at $\leq 25{ }^{\circ} \mathrm{C}$ (Fig. 1) for one year were acceptable for marketing for human consumption. The maximum acceptable postharvest colour darkening was then back calculated in $L^{*}, a^{*}$ and $b^{*}$ values and used as reference for acceptance of a sample.

Postharvest colour changes were also compared with the scale based on changes in Colour Difference Index $\left(\Delta \mathrm{E}_{\mathrm{ab}}^{*}\right.$ ) (Anonymous, 1989). It describes that $\Delta \mathrm{E}_{\mathrm{ab}}^{*}$ between 0 to 0.5 is a trace difference and impossible to be detected by human eyesight, 0.5 to 1.5 is slightly discernible and hard to detect by eye, 1.5 to 3.0 is noticeable and able to be detected by a trained panel, 3.0 to 6.0 is appreciable and detectable by ordinary people, a difference of 6.0 to 12.0 is large and indicates a large detectable difference in the same colour group and larger than 12.0 is extreme and indicates a shift to another colour group.

\subsection{Determination of Phenolic Constituents}

Total free phenolics, tannins and proanthocyanidins (PA) were determined in testa and cotyledons separately (Anonymous, 2000). Testa of 20 seeds were manually removed and the hilum excised and discarded (hilum consists of a small part of testa ( $\sim 5 \%)$ and has blackish colour that does not obviously change during storage). The testa was then ground with a grinder (IKA ${ }^{\circledR}$ A11 basic, IKA ${ }^{\circledR}$-WERKE GmbH \& Co. Germany). Cotyledons were ground separately. Testa $(0.2 \mathrm{~g})$ and cotyledons $(2 \mathrm{~g})$ were extracted with $20 \mathrm{ml}$ of $70 \% \mathrm{v} / \mathrm{v}$ aq. acetone (analytical grade) by applying 20 min ultrasonic treatment at $4{ }^{\circ} \mathrm{C}$ followed by overnight mechanical tumbling. Extracts were analysed for total phenolics by spectrophotometrical methods using the Folin-Ciocalteu's Phenol Reagent (Merck). Total phenolic compounds were calculated from a prepared standard curve of tannic acid (Merck) 
under same set of conditions. Tannins were complexed with polyvinylpolypyrrolidone (Sigma) and unbound non-tannin phenolics were determined as above (Anonymous, 2000). Total tannins were calculated by subtracting non-tannin phenolics from total phenolics. Proanthocyanidins were determined according to Butanol-HCl method of Porter, Hrstich, \& Chan (1986) given in (Anonymous, 2000).

\subsection{Statistical analysis}

Correlations and analyses of variance were carried out using SPSS 14.0 for Windows and means were separated using Tukey's Honestly Significant Difference (Tukey’s HSD) test at a significance level of 0.05 . Changes in Colour Difference Index $\left(\Delta \mathrm{E}^{*}\right.$ ab) of faba bean stored with different SMC at various temperatures were used to develop a predictive model in GenStat 2005 (GenStat for Windows, 8th Edition, VSN International Ltd, Rothamsted, England).

\section{Results}

\subsection{Effect of storage temperature and duration on the stability of postharvest testa colour}

Storage temperature and duration influenced faba bean testa colour. It changed from beige (initial colour) to medium brown in seeds stored at lower temperatures $\leqslant 25^{\circ} \mathrm{C}$ ) but changed to dark reddish brown and almost black in seeds stored at higher temperatures $\left.¥ 37{ }^{\circ} \mathrm{C}\right)$ after 12 months (Fig. 1). Both temperature and duration of storage influenced $L^{*}, a^{*}$ and $b^{*}$ values (Fig. 2). The higher the temperature the faster the rate of change in $L^{*}, a^{*}$ and $b^{*}$ values. There was a continuous decrease in $L^{*}$ and $b^{*}$ values with the passage of time at all temperatures. Lightness and yellowness in the initial beige coloured seeds was masked as colour changed through brown to dark reddish-brown. On the other hand, $a^{*}$ values increased and then 

after two weeks to a maximum $\left(a^{*}=16.8\right)$ and then decreased in seeds stored at $60{ }^{\circ} \mathrm{C}$ (Fig. 2$)$, whereas seeds stored at temperatures of 37,45 and $50{ }^{\circ} \mathrm{C}$ attained their maximum $a^{*}$ values $\left(a^{*} \sim 16\right)$ after 4,2 and 1 month respectively, followed by a continuous decrease indicating a similar path accelerated by temperature. Samples stored at temperatiㅛss ${ }^{\circ} \mathrm{C}$ did not achieve a similar high $a^{*}$ value after one year in storage. This change in $a^{*}$ values reflects a change in the red component of bean colour which increased due to an initial turning of bean colour to reddish-brown and then decreased due to a loss of the red component and an increase in darkness $\left(L^{*}\right)$.

The Colour Difference Index $\left(\Delta \mathrm{E}_{\mathrm{ab}}^{*}\right)$ for faba bean seeds increased during storage at all temperatures. Substantial colour changes $\left(\Delta \mathrm{E}^{*}{ }_{\mathrm{ab}}\right.$ values) were found during storage in all seed samples particularly those stored at higher temperatureş3 37 $\left.{ }^{\circ} \mathrm{C}\right)$. The higher the storage temperature the higher the change in colour after a given time period. The data demonstrated a positive correlation $(r=0.85)$ between storage temperature and the $\Delta \mathrm{E}{ }^{*}$ ab values. Appreciable postharvest colour changes detectable by ordinary people (Anonymous, 1989) occurred after 4 months at $5{ }^{\circ} \mathrm{C}$, after 2 months at 15 and $20{ }^{\circ} \mathrm{C}$, after 1 month at $25^{\circ} \mathrm{C}$ and after only two weeks in samples stored at or above $30^{\circ} \mathrm{C}$ (Fig. 2).

\subsection{Effect of seed moisture content and light on the stability of postharvest testa colour}

Seed moisture content (SMC) was also an important factor affecting postharvest colour darkening expressed by changes in $L^{*}, a^{*}$ and $b^{*}$ values. The higher the seed moisture content the faster was the darkening process at a given temperature. There was a positive correlation ( $\mathrm{r}$ $=0.88$ ) between SMC andE ${ }^{*}$ ab values. Samples with 8\% SMC were less susceptible to 
darkening compared to higher SMC. There was a continuous decrease in $L^{*}$ and $b^{*}$ values with the passage of time (Fig. 3). Seeds with 8\% SMC had a change of 27 points inE ${ }_{\text {ab }}^{*}$ values after 12 months storage at $37^{\circ} \mathrm{C}$ whereas seeds with 10, 12 and 14\% SMC exhibited the same level of change in just 8, 6 and 3 months respectively (Fig. 3).

Light also caused a substantial increase in postharvest colour darkening. Seeds stored under light darkened much faster than those stored in dark. Storage under light caused a faster decrease in $L^{*}$ and $b^{*}$ values and a faster increase in $a^{*}$ values (Fig. 4). Appreciable colour changes detectable by ordinary people (Anonymous, 1989) were measured just after 2 weeks storage under light at $20 \pm 2{ }^{\circ} \mathrm{C}$.

\subsection{Effect of storage temperature on the kernel (cotyledon) colour}

Not only testa colour but also kernel colour of faba beans darkened during storage at $37{ }^{\circ} \mathrm{C}$. Similar to testa colour cotyledon colour demonstrated a decrease in $L^{*}$ and $b^{*}$ values and an increase in $a^{*}$ values (Fig. 5). Cotyledon colour darkened less than testa colour but differences were still large (Anonymous, 1989). Cotyledons showed a change of 6 points ime ${ }^{*}$ ab values after 8 months storage at $37^{\circ} \mathrm{C}$ (Fig. 5).

\subsection{Predictive model for postharvest seed coat colour changes}

Using the data collected for changes in colour difference indexE $\left({ }^{*}\right.$ ab $)$ of faba bean seeds stored for 12 months under a range of storage conditions a predictive model was developed which is expressed in Eq. II:

$$
\mathrm{Y}=a(T+\mathrm{SMC}+T \times \mathrm{SMC})+b(T+\mathrm{SMC}+T \times \mathrm{SMC}) k^{\mathrm{P}}
$$

Eq. II 
224 Where $\mathrm{Y}=$ change in $\Delta \mathrm{E}^{*}$ ab values, $\mathrm{T}$ is storage temperature in ${ }^{\circ} \mathrm{C}$, SMC is $\%$ seed moisture 225 content, $\mathrm{P}$ is storage period in months.

$226 \quad a, b$ and $k$ are constants with the following values

$227 \quad a=0.063, b=-0.058$, and $k=0.583$

228 The equation accounted for 94\% variance provided that Fiesta variety is stored under constant 229 temperature and SMC in dark.

230

231

232

233

234

235

236

237

238

239

240

241

242

243

244

245

246

\subsection{Changes in Phenolic constituents with change in postharvest testa and cotyledon colour} Storage at different temperatures for 12 months led to substantial reduction in total free phenolic constituents especially in the testa and there was a greater decrease with higher storage temperature resulting in more darkening (Table 1). The reduction in total free phenolics after 12 months storage ranged from $5 \%$ at $5{ }^{\circ} \mathrm{C}$ to $76 \%$ at $50{ }^{\circ} \mathrm{C}$.

Tannins were the major proportion of total phenolics in the testa of faba bean. Tannin contents were negatively correlated with postharvest colour darkening in faba bean but the decrease was not significant for seeds stored under cooler temperatures up to $25^{\circ} \mathrm{C}$ (Table 1 ). Nontannin phenolics also decreased, with an accompanying increase in darkening, with higher storage temperature. Testa of freshly harvested faba bean seeds contained $18.8 \mathrm{mg} \mathrm{g}^{-1}$ nontannin phenolics (Table 1) which decreased by 12- 86\% for seeds stored over the range of 5-50 ${ }^{\circ} \mathrm{C}$ after 12 months. Proanthocyanidins, which were the predominant group among tannins also substantially decreased (Table 1) with an increased storage temperature especially higher temperatures $\left(\geq 37^{\circ} \mathrm{C}\right)$.

Storage under light at $20^{\circ} \mathrm{C}$ caused substantial changes in phenolic contents compared with the samples stored in dark at the same temperature. Samples stored under light for 12 months 
showed a 46\% decrease in total phenolics and 57\% decrease in PA whereas samples stored in dark showed only 9\% decrease in total phenolics and 13\% decrease in PA (Table 2). Storage at higher temperature $\left(25^{\circ} \mathrm{C}\right)$ also affected total phenolic contents of the cotyledon. Total phenolics of cotyledons consistently decreased with increased storage temperature especially storage at higher temperatures $\left(\geq 37^{\circ} \mathrm{C}\right)$ in dark (Table 3$)$.

\section{Discussion}

\subsection{Effect of storage temperature and duration on the stability of testa colour}

It is possible to store faba beans without substantial darkening. Our results show that postharvest seed coat colour darkening in faba bean was slow at moderate to low temperatures $\left(\leq 25^{\circ} \mathrm{C}\right)$ and it was slowest and therefore had best colour retention after 12 months at $5^{\circ} \mathrm{C}$. Low temperature also slows postharvest seed coat colour darkening in other legumes. Little change in seed coat colour occurs in Rwandan dry beans (Phaseolus vulgaris) stored at $4{ }^{\circ} \mathrm{C}$ for 24 months (Edmister et al., 1990). Light red kidney beans (Phaseolus vulgaris L.) also retain their original colour for one year when stored at $1{ }^{\circ} \mathrm{C}$ (Gunes et al., 1997). In lentil seeds (Lens culinaris Medic.) there is no darkening at $5{ }^{\circ} \mathrm{C}$ (Nordstorm et al., 1979) and it is slow in adzuki beans (Vigna angularis) at $10{ }^{\circ} \mathrm{C}$ (Yousif et al., 2003). So similar to other legumes, storage at $5{ }^{\circ} \mathrm{C}$ best protected faba bean postharvest colour during long term storage.

Storage of faba bean at high temperatures $\left(230^{\circ} \mathrm{C}\right)$ accelerated colour darkening especially at $\geq 37^{\circ} \mathrm{C}$. This supports earlier evidence that high temperature storage is an important factor causing postharvest colour darkening in faba bean and other legume seeds (Amarowicz, Troszynska, Barylko-Pikielna \& Shahidi, 2004; Cunha, Sgarbieri \& Damasio, 1993; Quast \& 
Silva, 1977; Sorour \& Uchino, 2004). Davies (1994) also found that storage of faba beans at $40^{\circ} \mathrm{C}$ causes a substantial increase in postharvest colour darkening. Adzuki beans (Yousif et al., 2003), Rawandan dry beans (Edmister et al., 1990) and lentil seeds (Nozzolillo et al., 1984) also darken when stored at $30^{\circ} \mathrm{C}$. Seeds stored at high temperatures $\left(237^{\circ} \mathrm{C}\right)$ darkened to an unacceptable level of marketing for human consumption in less than 3 months.

In general, postharvest faba bean seed coat darkening increased with increased temperature but duration of storage must be taken into account. Long term storage caused colour darkening even at intermediate temperatures $\left(15,20\right.$ and $\left.25^{\circ} \mathrm{C}\right)$ as in other legumes. Storage at $24{ }^{\circ} \mathrm{C}$ for one year increases darkening in light-red kidney beans (Hughes et al., 1975) and Rwandan dry beans colour darkened when stored at $23{ }^{\circ} \mathrm{C}$ for 24 months (Edmister et al., 1990). Long term storage of faba bean at temperatures $\leq 25^{\circ} \mathrm{C}$ darkened seed coat colour but the darkening level was in the acceptable range of marketing for human consumption after 12 months. This contrasted with storage at $\geq 37{ }^{\circ} \mathrm{C}$ which caused substantial darkening just after 2 weeks and the seeds became unacceptably dark (brown) for human consumption in less than 3 months.

The accelerated colour darkening process in faba bean at high temperaturere7 $\left.{ }^{\circ} \mathrm{C}\right)$ is a serious concern for on-farm storage in Western Australia. The faba bean crop is harvested in the beginning of summer (November-December) and grain is stored on farm for the next couple of months. The air temperature may rise above $40^{\circ} \mathrm{C}$ (Bureau of Meteorology, Western Australia), which can quickly cause colour darkening and lower the quality of the produce. Conversely storage of faba bean at refrigeration temperatures $\left(\sim 5^{\circ} \mathrm{C}\right)$ would protect faba bean colour during long term storage but its practical use, especially considering the cost of storage, 
would be prohibitive commercially. A maximum storage temperature, which would keep faba bean colour darkening to an acceptable level for marketing for human consumption, was $\leq 25$ ${ }^{\circ} \mathrm{C}$ and this may be practical at commercial level.

\subsection{Effect of seed moisture content and light on the stability of postharvest testa colour}

Seed moisture content was also recognized as an important factor in colour darkening of faba bean. Seeds with higher SMC darkened at faster rate than those having lower SMC. Seeds with 8\% SMC were very resistant to colour darkening as compared to those with higher SMC. High SMC and/or high relative humidity in the storage environment have been identified by other researchers as major factors responsible for the deterioration of quality traits including colour of other species of bean. In pinto beans (Phaseolus vulgaris) seeds with $10 \%$ added moisture have greater colour change (decrease in Hunter $L^{*}$ values and increase in a* values) than control seeds or seeds with 5\% added moisture (Park et al., 1999). Increases in postharvest colour darkening in Rwandan dry beans positively relate to increase in water activity $\left(\mathrm{a}_{\mathrm{w}}\right)$ across a range of storage temperatures (Edmister et al., 1990).

Farmers need to harvest faba beans early and at high moisture contents (14-15\%) to preserve seed quality and maximise yield. Harvesting early is important because the longer the crop remains in the field the more vulnerable it is to loss from lodging and pod shedding. Our results revealed that a $14-15 \%$ moisture content of faba bean accelerates postharvest colour darkening considerably during storage. So, in order to maintain faba bean colour for human consumption during long term storage, faba bean could be dehydrated to $8-10 \%$ SMC after harvesting. The extra cost of dehydration and reduced yield (by weight) may be compensated for by the higher sale price and this requires a cost-benefit analysis. 
317 Light also substantially affected faba bean colour during storage. Testa darkening under light 318 for one month was equal to darkening in 12 months in dark at the same temperature (20 \pm 2 $319{ }^{\circ} \mathrm{C}$ ). The observed light acceleration of colour darkening in faba bean extends earlier research 320 on the effect of light on other legumes. Ultraviolet and cool-white light darkens light-red 321 kidney beans during storage (Hughes et al., 1975). Similarly parts of faba bean seeds were observed to darken when they were exposed to light when pods split on the plant. Growers of light-red kidney beans also observe darkening of beans in pods when harvest is delayed after pods and seeds are fully mature (Hughes et al., 1975).

Postharvest colour darkening in faba beans due to light may be of less concern to producers because seeds get exposed to light for a very short period. There is generally little pod splitting in field. After harvesting faba beans are stored in metal bins/silos where no light can penetrate. The only possibility of exposure to light is when they are packed in 50-100 kg bags made of white polypropylene weave bags at around 650 denier (most commonly used packing material), which is semi transparent, and subsequent storage where they are exposed to light/sunlight. Either this practice should be avoided or a non-transparent material should be used for packaging faba beans for retailing.

\subsection{Effect of storage temperature on the kernel (cotyledon) colour}

336 Substantial colour changes in kernel (cotyledon) colour were also determined in seeds stored 337 at higher temperature $\left(37^{\circ} \mathrm{C}\right)$. Darkening of faba bean cotyledons is important for the 338 dishes/products where cotyledon colour is visible e.g. Falafel (deep fried dough) and Bissara 
(poured paste) in Egypt and other Middle Eastern countries. This affects sensory quality of the products and hence their marketability.

\subsection{Predictive model}

The predictive model for postharvest seed coat colour changes will be helpful for farmers and exporters/importers to calculate and predict the storage life of faba beans. This will enable them to determine the limit of storage for colour changes to remain acceptable for marketing for human consumption and hence increase profitability.

\subsection{Changes in phenolic constituents with change in postharvest testa and cotyledon colour}

A substantial reduction in phenolic compounds was associated with postharvest colour darkening in faba beans. Total free phenolic contents of testa demonstrated a $5 \%$ to $76 \%$ decrease whereas non-tannin phenolics demonstrated a $12 \%$ to $86 \%$ decrease in seeds stored across a temperature range of $5-50^{\circ} \mathrm{C}$. Polyphenols in other legumes behave similarly (Hincks \& Stanley, 1986). A range of cultivars of dry beans (Phaseolus vulgaris) stored for 5 years under tropical conditions $\left(30-40{ }^{\circ} \mathrm{C}, 75 \% \mathrm{RH}\right)$ exhibit an $11 \%$ to $38 \%$ decrease in total polyphenols and a substantial decrease in non-tannin polyphenols as compared with freshly harvested beans (Martin-Cabrejas, Esteban, Perez, Maina \& Waldron, 1997). A reduction in polyphenol content is found at all stages of seed development in winged beans (Psophocarpus tetragonolobus L.) (Kadam, Kute, Lawande \& Salunkhe, 1982). The reduction in total free phenolics and non-tannin phenolics is probably due to polymerization of existing polyphenolic compounds, resulting in insoluble, high molecular weight polymers. Browning in lentil seeds is also assumed to be the result of polymerisation of low molecular weight phenolic precursors to brown-coloured high molecular weight products (Nozzolillo et al., 1984). The decrease in 
phenolic constituents with the increase in colour darkening may also be due to oxidative degradation of particular phenolic compounds (Marquardt, Ward \& Evans, 1978). Phenolic compounds vary widely in complexity but their common characteristic is that they are readily oxidised and undergo phenolic reactions (Bors, Heller, Michel \& Stettmaier, 1996). Indeed when faba beans are flushed with oxygen darkening accelerates, whereas flushing with nitrogen reduces it (Nasar-Abbas, Plummer, Siddique, White, Harris \& Dods, 2008). Further, storage of several varieties of faba beans under low oxygen concentration reduces colour darkening suggesting that darkening is due to oxidation of polyphenolics (Black \& Brouwer, 1998). Oxidation of polyphenols, and especially non-tannin polyphenols, might also be due to peroxidase enzyme activity which continues during postharvest storage (Fry, 1986). Others suggest that the darkening is probably due to a combination of Maillard (non-enzymatic) browning and chemical changes involving phenolic compounds (Edmister et al., 1990). It is possible that any or all of these processes are involved in the complex chemistry associated with postharvest seed coat colour darkening of faba bean.

Tannin especially PA (condensed tannin) may be involved in colour darkening of faba bean. Pinto bean variety with higher initial PA contents darkened faster than the one with lower PA contents (Beninger, Gu, Prior, Junk, Vandenberg \& Bett, 2005). The continuous decrease in tannin contents including PA with the increase in darkening of seed testa supports studies in different beans. A decrease in PA of faba beans with colour darkening is also caused by accelerated aging at $40{ }^{\circ} \mathrm{C}$ and $100 \%$ RH (Davies, 1994). In lentils there is a substantial reduction in proanthocyanidin contents as they change colour from green to dark brown during storage (Nozzolillo et al., 1984). Tannins increase gradually in black beans (Phaseolus vulgaris) during storage at $5{ }^{\circ} \mathrm{C}$ for 6 months whereas they increase, reach a plateau and then 
decline when stored at elevated temperatures of $30^{\circ} \mathrm{C}$ and $40^{\circ} \mathrm{C}$ (Sievwright \& Shipe, 1986). This suggests that tannins continue to develop from smaller molecular weight non-tannin material during storage but at higher temperatures there is a loss of tannins due to their binding with macro-molecules (proteins).

Our studies revealed that at lower temperatures $\left(\leqslant 25^{\circ} \mathrm{C}\right)$ a non-significant reduction in tannin contents occurred whereas at higher temperatures $3\left(7 \quad{ }^{\circ} \mathrm{C}\right)$ significant reductions were determined. This might have been due to a balance between development of tannins from smaller molecular weight, non-tannin material (Bors et al., 1996; Hughes et al., 1975; Marquardt et al., 1978) and subsequent binding with proteins at lower temperatures. At high temperatures $\left(\gtrless 37^{\circ} \mathrm{C}\right)$ this balance may have shifted towards binding with proteins due to increased biochemical activity (Sievwright et al., 1986). The loss in tannin content might also be due to their strong antioxidant activity (Shahidi, Chavan, Naczk \& Amarowicz, 2001). Proanthocyanidins are damaged by oxidative reactions, as they play an important role in the defence system of seeds exposed to oxidative damage caused by environmental factors such as light, oxygen, free radicals and metal ions (Amarowicz et al., 2004; Troszynska \& Ciska, 2002). Proanthocyanidins are known to prevent lipid oxidation as reducing agents, free radical scavengers and chelators of pro-oxidant catalytic metals. Tannins are 15-30 times more effective in the quenching of peroxyl radicals than simple phenolics (Hagerman et al., 1998).

Light changed phenolic contents in the testa but it was not effective in changing cotyledon phenolic content. Light may only affect the testa of beans. The testa, which is the outermost portion of the seed, may filter or block light from reaching the cotyledons. The testa however, would not be able to insulate the cotyledons from a constant external temperature and the 
whole seed would quickly equilibrate with air temperature. Ultraviolet and cool-white light darken kidney beans in storage but seeds darkened by light decrease very little in cooking quality in contrast to seeds darkened by high storage temperature and relative humidity. Darkening caused by light probably involves only pigment changes in the seed coat whereas darkening caused by high temperature involves changes in constituents throughout the seed. Similar light induced changes in the seed testa, but not cotyledons, may also occur in faba bean.

\section{References}

AACC (2000). Approved Methods of the American Association of Cereal Chemists Minnesota: American Association of Cereal Chemists, Inc.

AGWEST (1998). Pulse Quality Guide: Faba bean. Agriculture Western Australia, 3 BaronHay Court, 6151, WA, Australia.

Amarowicz, R., Troszynska, A., Barylko-Pikielna, N., \& Shahidi, F. (2004). Polyphenolics extracts from legume seeds: correlations between total antioxidant activity, total phenolics content, tannins content and astringency. Journal of Food Lipids, 11(4), 278-286.

Anonymous (1989). Handbook of Colour Science. Japanese Academy of Colour Science Anonymous (1991). Chroma Meter (CR-300/CR-310/CR-321/CR-331/CR-331C), Instruction Manual. Tokyo: Minolta Co. Ltd.

Anonymous (2000). Quantification of Tannins in Tree Foliage. Joint FAO/IAEA Division of Nuclear Techniques in Food and Agriculture, Vienna.

Beninger, C. W., Gu, L., Prior, R. L., Junk, D. C., Vandenberg, A., \& Bett, K. E. (2005). Changes in polyphenols of the seed coat during after-darkening process in pinto beans (Phaseolus vulgaris L.). Journal of Agricultural and Food Chemistry, 53(20), 7777-7782.

Black, R. G., \& Brouwer, J. B. (1998). Effect of storage conditions over 12 months on the colour of faba beans (Vicia faba L.). In: Opportunities for high quality, healthy and added value crops to meet European demands. Proceedings of the 3rd European conference on grain legumes, Valladolid, Spain 14-19 Nov. European Association for Grain Legume Research, Paris, France. 
Bors, W., Heller, W., Michel, C., \& Stettmaier, K. (1996). Flavonoids and polyphenols: Chemistry and biology. In: Cardenas E and Packer L (Eds.). Handbook of Antioxidants. Marcel Dekker, New York, pp 409-466.

Cunha, M. F., Sgarbieri, V. C., \& Damasio, M. H. (1993). Effects of pretreatment with gamma rays or microwaves on storage stability of dry beans. Journal of Agricultural and Food Chemistry, 41(10), 1710-1715.

Davies, S. L. (1994). Seed discolouration in faba beans (Vicia faba L.), Honours thesis. Department of Plant Science, Waite Agricultural Research Institute Adelaide: University of Adelaide.

Dickinson, D., Knight, H., \& Rees, D. I. (1957). Varieties of broad beans suitable for canning. Chemistry and Industry, 16, 1503.

Edmister, J. A., Breene, W. M., \& Serugendo, A. (1990). Influence of temperature, water activity and time on cookability and color of a stored Rwandan dry bean (Phaseolus vulgaris) mixture. Journal of Stored Products Research 26(3), 121-126.

Fry, S. C. (1986). Cross-linking of matrix polymers in the growing cell walls of angiosperm. Annual Review of Plant Physiology, 37, 165-186.

Gunes, G., \& Lee, C. Y. (1997). Color of minimally processed potatoes as affected by modified atmosphere packaging and antibrowning agents. Journal of Food Science, 62(3), 572-575.

Hagerman, A. E., Riedl, K. M., Jones, G. A., Sovik, K. N., Ritchard, N. T., Hartzfeld, P. W., \& Riechel, T. L. (1998). High molecular weight plant polyphenolics (tannins) as biological antioxidants. Journal of Agricultural and Food Chemistry, 46(5), 1887-1892.

Hincks, M. J., \& Stanley, D. W. (1986). Multiple mechanisms of bean hardening. Food Technology, 21, 731-750.

Hughes, P. A., \& Sandsted, R. F. (1975). Effect of temperature, relative humidity and light on the color of 'California Light Red Kidney' bean seeds during storage. Hortscience, 10, 421423.

Kadam, S. S., Kute, L. S., Lawande, K. M., \& Salunkhe, D. K. (1982). Changes in chemical composition od winged beans (Psophocarpus tetragonolobus) during seed development. Journal of Food Science, 47, 2051-2057.

Marquardt, R. R., Ward, A. T., \& Evans, L. E. (1978). Comparative properties of tannin-free and tannin-containing cultivars of faba beans (Vicia faba) Canadian Journal of Plant Science, $58,753-760$.

Martin-Cabrejas, M. A., Esteban, R. M., Perez, P., Maina, G., \& Waldron, K. W. (1997). Changes in physicochemical properties of dry beans (Phaseolus vulgaris L.) during long term storage. Journal of Agricultural and Food Chemistry, 45(8), 3223-3227. 
477

478

479

480

481

482

483

484

485

486

487

488

489

490

491

492

493

494

495

496

497

498

499

500

501

502

503

504

505

506

507

508

509

510

511

Nasar-Abbas, S. M., Plummer, J. A., Siddique, K. H. M., White, P., Harris, D., \& Dods, K. (2008). Nitrogen retards and oxygen accelerates colour darkening in faba bean (Vicia faba L.) during storage. Postharvest Biology and Technology, 47, 113-118.

Nordstorm, C. L., \& Sistrunk, W. A. (1977). Effect of type of bean, soak time, canning media and storage time on quality attributes and nutrient content of canned dry beans. Journal of Food Science, 42, 795-798.

Nordstorm, C. L., \& Sistrunk, W. A. (1979). Effect of type of bean, moisture level, blanch treatment and storage time on quality attributes and nutrient content of canned dry beans. Journal of Food Science, 44(392-395, 403.).

Nozzolillo, C., \& De Bezada, M. (1984). Browning of lentil seeds, concomitant loss of viability, and the possible role of soluble tannins in both phenomena. Canadian Journal of Plant Science 64, 815-824.

Park, D., \& Maga, J. A. (1999). Dry bean (Phaseolus vulgaris) color stability as influenced by time and moisture content. Journal of Food Processing and Preservation 23(6), 515-522.

Porter, L. J., Hrstich, L. N., \& Chan, B. G. (1986). The conversion of proanthocyanidins and prodelphinidins to cyanidin and delphinidin. Phytochemistry, 25, 223-230.

Quast, D. G., \& Silva, S. D. (1977). Temperature dependence of hydration rate and effect of hydration on cooking rate of dry legumes. Journal of Food Science, 42, 1299-1303.

Reyes-Moreno, C., Okamura-Esparza, J., Armienta-Rodelo, E., Gomez-Garza, R. M., \& Milan-Carrillo, J. (2000). Hard-to-cook phenomenon in chickpeas (Cicer arietinum L.): effect of accelerated storage on quality. Plant Foods for Human Nutrition, 55(3), 229-241.

Robertson, L. D., \& El-Sherbeeny, M. (1991). Distribution of discretely scored descriptors in a pure line faba bean Vicia faba L. germplasm collection. Euphytica, 57(1), 83-92.

Shahidi, F., Chavan, U. D., Naczk, M., \& Amarowicz, R. (2001). Nutrient distribution and phenolic antioxidants in air-classified fraction of beach pea (Lathyrus maritimus L.). Journal of Agricultural and Food Chemistry, 49, 926-933.

Sievwright, C. A., \& Shipe, W. F. (1986). Effect of storage conditions and chemical treatments on firmness, in vitro protein digestibility, condensed tannins, phytic acid and divalent cations of cooked black beans (Phaseolus vulgaris). Journal of Food Science, 51(4), 982-987.

Sorour, H., \& Uchino, T. (2004). Effect of changing temperature on the deterioration of soya bean. Biosystems Engineering, 87(4), 453-462.

Troszynska, A., \& Ciska, E. (2002). Phenolic compounds of seed coats of white and coloured varieties of pea (Pisum sativum L.) and their total antioxidant activity. Szech Journal of Food Science 20, 15-22. 
Wexler, A. (1997). Constant humidity solutions. In: Lide DR (ed.) Handbook of Chemistry and Physics, 78th Ed. CRC press, New York, pp. 15, 25-26.

Yousif, A. M., Kato, J., \& Deeth, H. C. (2003). Effect of storage time and conditions on the seed coat colour of Australian adzuki beans. Food Australia, 55(10), 479-484.

Table 1. Phenolic constituents of testa of faba beans stored at different temperatures for 12 months

\begin{tabular}{llllc}
\hline Storage treatments & $\begin{array}{l}\text { Total free } \\
\text { phenolics (mg } \\
\text { tannic acid g })\end{array}$ & $\begin{array}{l}\text { Non-tannin } \\
\text { phenolics }(\mathrm{mg} \\
\text { tannic acid g }\end{array}$ & $\begin{array}{l}\text { Total tannins } \\
(\mathrm{mg} \text { tannic acid }\end{array}$ & $\begin{array}{l}\text { Proanthocyanidins } \\
\left.\mathrm{g}^{-1}\right)\end{array}$ \\
\hline Control & & & & \\
(Freshly harvested) & $62.4 \pm 0.4^{\mathrm{a}}$ & $18.8 \pm 0.4^{\mathrm{a}}$ & $43.6 \pm 0.6^{\mathrm{a}}$ & $40.7 \pm 0.1^{\mathrm{a}}$ \\
$5^{\circ} \mathrm{C}$ in dark & $59.5 \pm 0.3^{\mathrm{b}}$ & $16.5 \pm 0.3^{\mathrm{b}}$ & $43.0 \pm 0.3^{\mathrm{a}}$ & $38.7 \pm 1.4^{\mathrm{a}}$ \\
$15^{\circ} \mathrm{C}$ in dark & $57.1 \pm 0.9^{\mathrm{bc}}$ & $15.7 \pm 0.1^{\mathrm{bc}}$ & $41.4 \pm 0.8^{\mathrm{a}}$ & $35.7 \pm 1.3^{\mathrm{b}}$ \\
$25^{\circ} \mathrm{C}$ in dark & $55.9 \pm 1.3^{\mathrm{c}}$ & $15.2 \pm 0.5^{\mathrm{cd}}$ & $40.7 \pm 0.9^{\mathrm{a}}$ & $34.8 \pm 1.4^{\mathrm{b}}$ \\
$37^{\circ} \mathrm{C}$ in dark & $50.6 \pm 0.9^{\mathrm{d}}$ & $14.5 \pm 0.4^{\mathrm{d}}$ & $36.1 \pm 1.2^{\mathrm{b}}$ & $30.2 \pm 1.0^{\mathrm{c}}$ \\
$45^{\circ} \mathrm{C}$ in dark & $41.2 \pm 0.7^{\mathrm{e}}$ & $11.3 \pm 0.4^{\mathrm{e}}$ & $30.0 \pm 1.1^{\mathrm{c}}$ & $24.2 \pm 0.4^{\mathrm{d}}$ \\
$50^{\circ} \mathrm{C}$ in dark & $15.0 \pm 0.8^{\mathrm{f}}$ & $2.7 \pm 0.1^{\mathrm{f}}$ & $12.2 \pm 0.8^{\mathrm{d}}$ & $5.9 \pm 0.1^{\mathrm{e}}$ \\
\hline
\end{tabular}

Means ( \pm s.e., $n=3)$ sharing the same letter in a column are not significantly different $(p \leq 0.05)$ according to Tukey's HSD test.

Table 2. Phenolic constituents of testa of faba beans stored at $20^{\circ} \mathrm{C}$ under artificial light and dark for different time periods

\begin{tabular}{|c|c|c|c|c|}
\hline $\begin{array}{l}\text { Storage period } \\
\text { (months) }\end{array}$ & $\begin{array}{l}\text { Total free } \\
\text { phenolics (mg } \\
\text { tannic acid } \mathrm{g}^{-1} \text { ) }\end{array}$ & $\begin{array}{l}\text { Non-tannin } \\
\text { phenolics (mg } \\
\text { tannic acid g }{ }^{-1} \text { ) }\end{array}$ & $\begin{array}{l}\text { Total tannins } \\
(\mathrm{mg} \text { tannic acid } \\
\mathrm{g}^{-1} \text { ) }\end{array}$ & $\begin{array}{l}\text { Proanthocyanidins } \\
\left(\text { mg leucocyanidin } \mathrm{g}^{-1} \text { ) }\right.\end{array}$ \\
\hline $\begin{array}{l}0 \text { (Freshly } \\
\text { harvested; control) }\end{array}$ & $62.4 \pm 0.4^{\mathrm{a}}$ & $18.8 \pm 0.4^{\mathrm{a}}$ & $43.6 \pm 0.6^{\mathrm{a}}$ & $40.7 \pm 0.1^{\mathrm{a}}$ \\
\hline 1 (under light) & $52.4 \pm 1.0^{\mathrm{c}}$ & $14.6 \pm 0.4^{\mathrm{c}}$ & $37.8 \pm 0.6^{c}$ & $31.9 \pm 1.4^{\mathrm{c}}$ \\
\hline 3 (under light) & $46.5 \pm 1.2^{d}$ & $12.1 \pm 0.4^{\mathrm{d}}$ & $34.4 \pm 1.4^{d}$ & $28.8 \pm 1.0^{d}$ \\
\hline 6 (under light) & $42.3 \pm 0.8^{\mathrm{e}}$ & $11.6 \pm 0.2^{d}$ & $30.8 \pm 0.7^{\mathrm{e}}$ & $24.2 \pm 1.0^{\mathrm{e}}$ \\
\hline 9 (under light) & $36.0 \pm 1.3^{f}$ & $9.5 \pm 0.2^{\mathrm{e}}$ & $26.4 \pm 1.5^{\mathrm{f}}$ & $20.3 \pm 0.6^{f}$ \\
\hline 12 (under light) & $33.5 \pm 0.9^{f}$ & $8.3 \pm 0.1^{\mathrm{f}}$ & $25.2 \pm 0.9^{f}$ & $17.6 \pm 1.2^{\mathrm{f}}$ \\
\hline 12 (in dark) & $56.6 \pm 0.7^{b}$ & $15.6 \pm 0.2^{b}$ & $41.1 \pm 0.4^{b}$ & $35.5 \pm 0.3^{b}$ \\
\hline
\end{tabular}


536 Table 3. Total free phenolic contents of cotyledon of

537 faba beans stored at different temperatures in dark

538 and stored at $20^{\circ} \mathrm{C}$ under artificial light for 12 months

539

Total free phenolics
$\left(\mathrm{mg} \mathrm{tannic} \mathrm{acid} \mathrm{g}^{-1}\right)$

Freshly harvested (control) $\quad 1.71 \pm 0.01^{\mathrm{a}}$

Stored at $5{ }^{\circ} \mathrm{C}$ in dark $\quad 1.62 \pm 0.06^{\mathrm{ab}}$

Stored at $15{ }^{\circ} \mathrm{C}$ in dark $\quad 1.61 \pm 0.06{ }^{\mathrm{ab}}$

Stored at $20{ }^{\circ} \mathrm{C}$ in dark $\quad 1.58 \pm 0.05^{\mathrm{ab}}$

Stored at $25^{\circ} \mathrm{C}$ in dark $\quad 1.52 \pm 0.03^{\text {bc }}$

Stored at $37{ }^{\circ} \mathrm{C}$ in dark $\quad 1.46 \pm 0.06{ }^{\mathrm{cd}}$

Stored at $45^{\circ} \mathrm{C}$ in dark $\quad 1.34 \pm 0.04$ de

Stored at $50{ }^{\circ} \mathrm{C}$ in dark $\quad 1.29 \pm 0.04^{\mathrm{e}}$

Stored at $20{ }^{\circ} \mathrm{C}$ in light $\quad 1.59 \pm 0.01^{\mathrm{ab}}$

$540 \quad$ Means ( \pm s.e., $n=3$ ) sharing the same letter in the column are not

541 significantly different $(\mathrm{p} \leq 0.05)$ according to Tukey's HSD test

542

543 


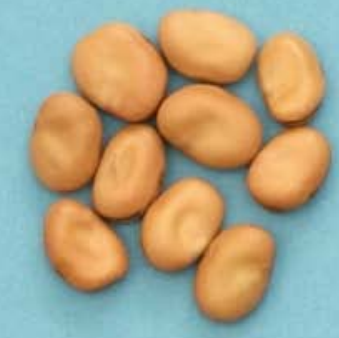

$5^{\circ} \mathrm{C}$

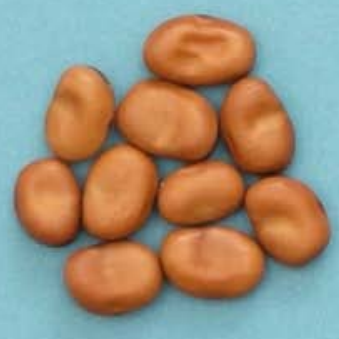

$25^{\circ} \mathrm{C}$

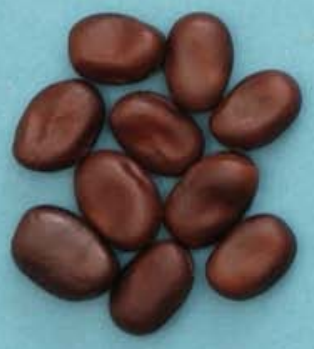

$45^{\circ} \mathrm{C}$

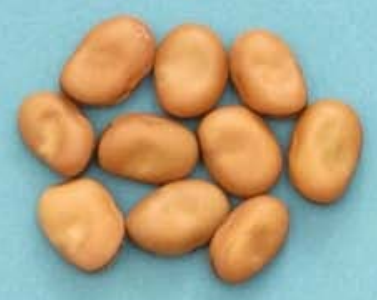

$15^{\circ} \mathrm{C}$

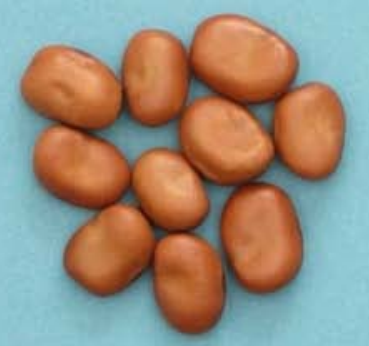

$30^{\circ} \mathrm{C}$

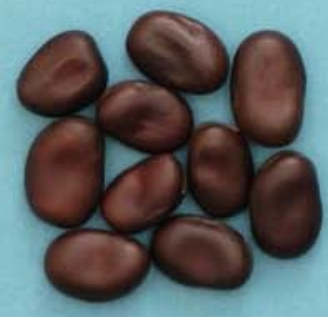

$50^{\circ} \mathrm{C}$
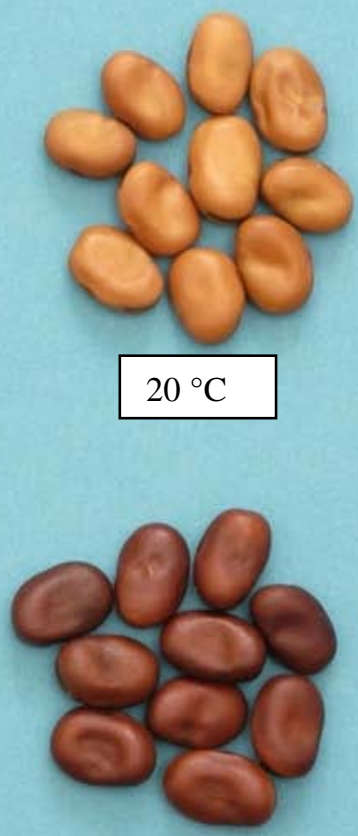

$37^{\circ} \mathrm{C}$

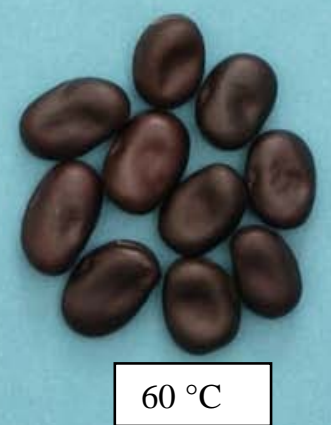

544

545

546

547

548

Fig. 1. Effect of temperature on the colour of faba bean seeds after12 month storage in dark. 


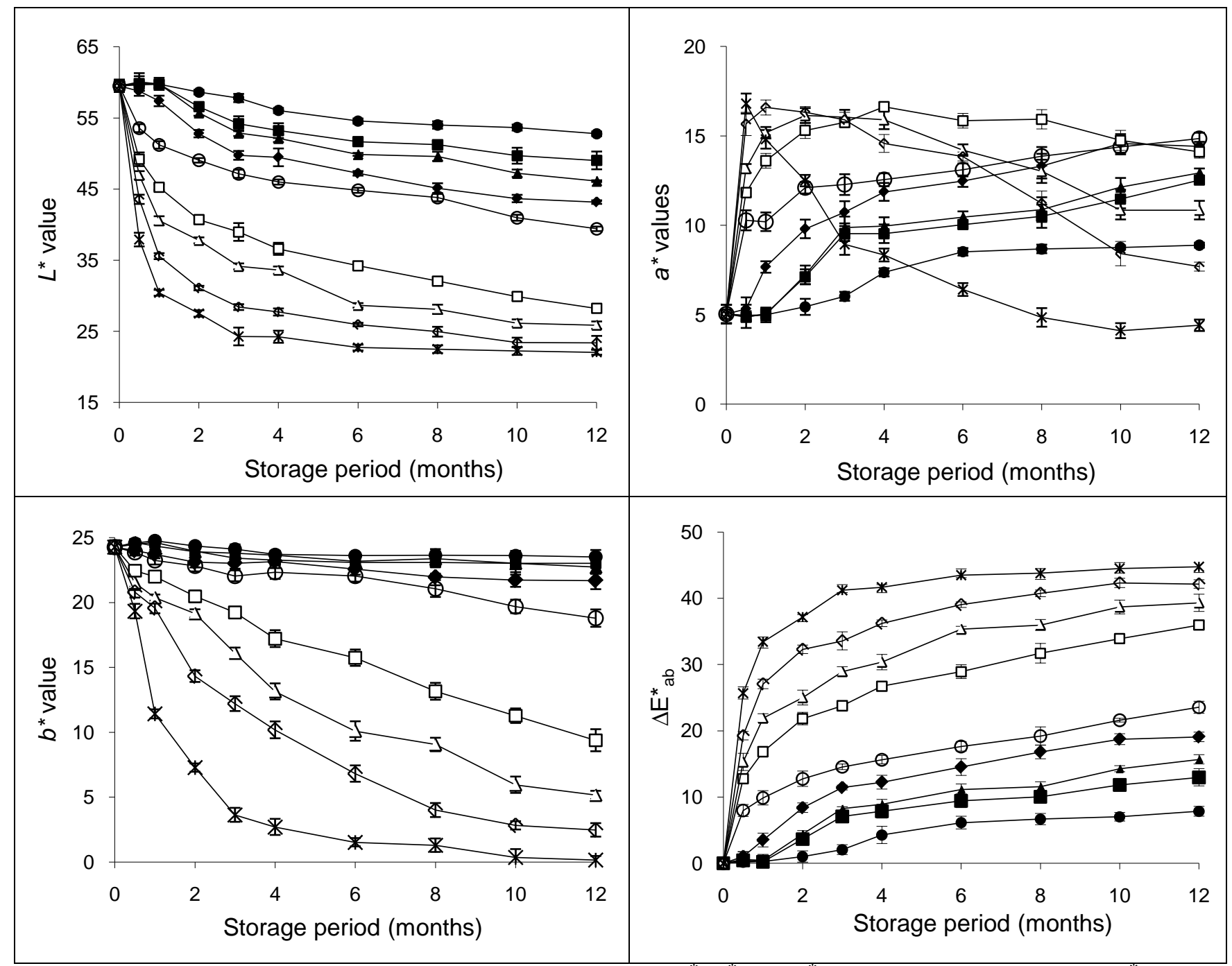

549 Fig. 2. Effect of storage time and temperature on $L^{*}, a^{*}$ and $b^{*}$ colour coordinates and $\Delta \mathrm{E}^{*}{ }_{\text {ab }}$

550 values of faba bean seeds stored in dark: $5{ }^{\circ} \mathrm{C}(\bullet), 15^{\circ} \mathrm{C}(\boldsymbol{\bullet}), 20^{\circ} \mathrm{C}(\boldsymbol{\Delta}), 25^{\circ} \mathrm{C}(\diamond), 30^{\circ} \mathrm{C}(\circ)$,

$55137^{\circ} \mathrm{C}(\square), 45^{\circ} \mathrm{C}(\Delta), 50^{\circ} \mathrm{C}(\diamond), 60^{\circ} \mathrm{C}(ж)$. Error bars $= \pm$ s.d., $\mathrm{n}=9$.

552

553

554 


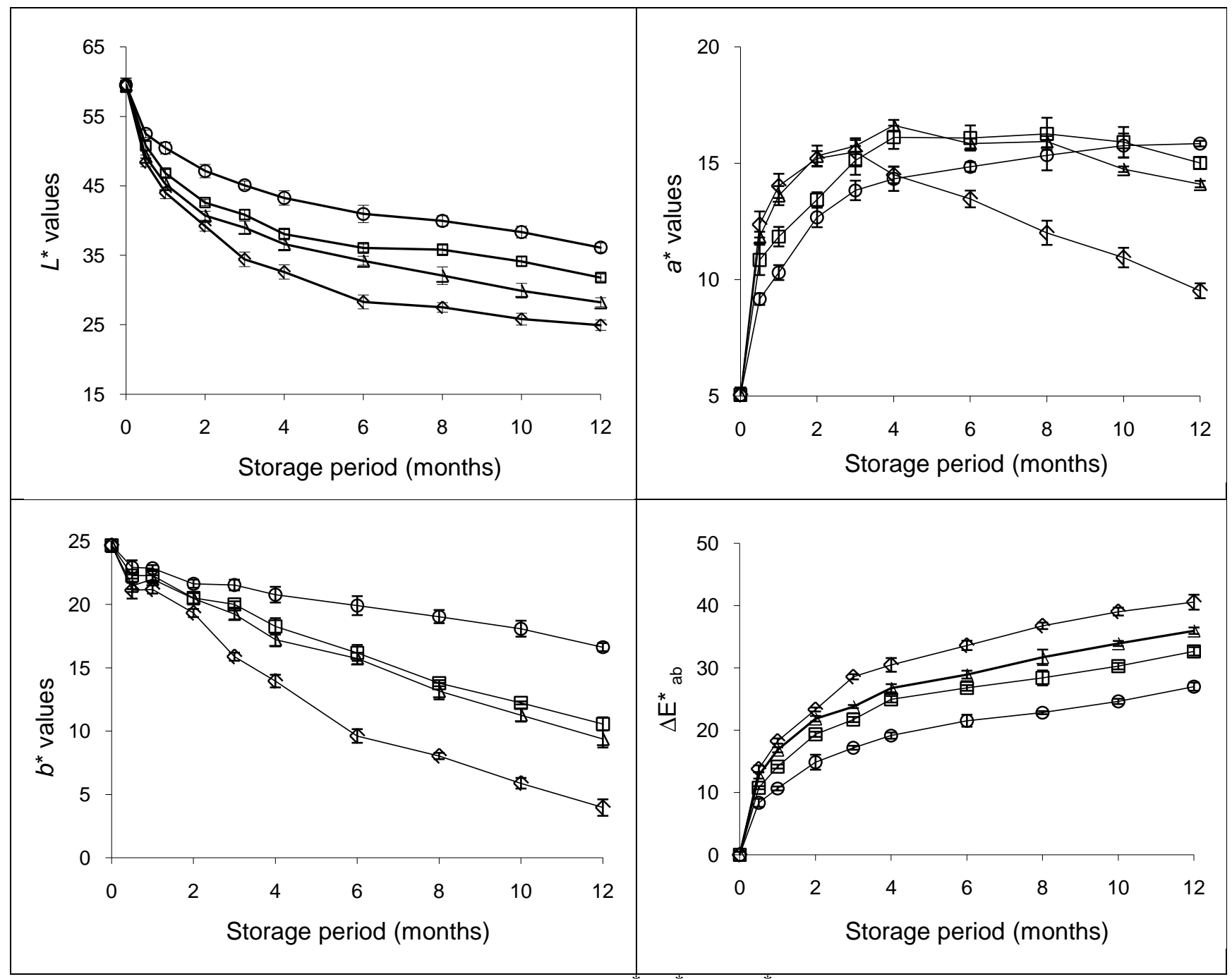

555 Fig. 3. Effect of seed moisture content on $L^{*}, a^{*}$ and $b^{*}$ colour coordinates and total colour 556 change $\left(\Delta \mathrm{E}^{*}\right.$ ab values) of faba bean seeds stored at $37{ }^{\circ} \mathrm{C}$ for 12 months in dark: 8\% SMC (०), $557 \quad 10 \% \operatorname{SMC}(\square), 12 \% \operatorname{SMC}(\Delta), 14 \% \operatorname{SMC}(\diamond)$. Error bars $= \pm$ s.d., $\mathrm{n}=9$.

558

559 


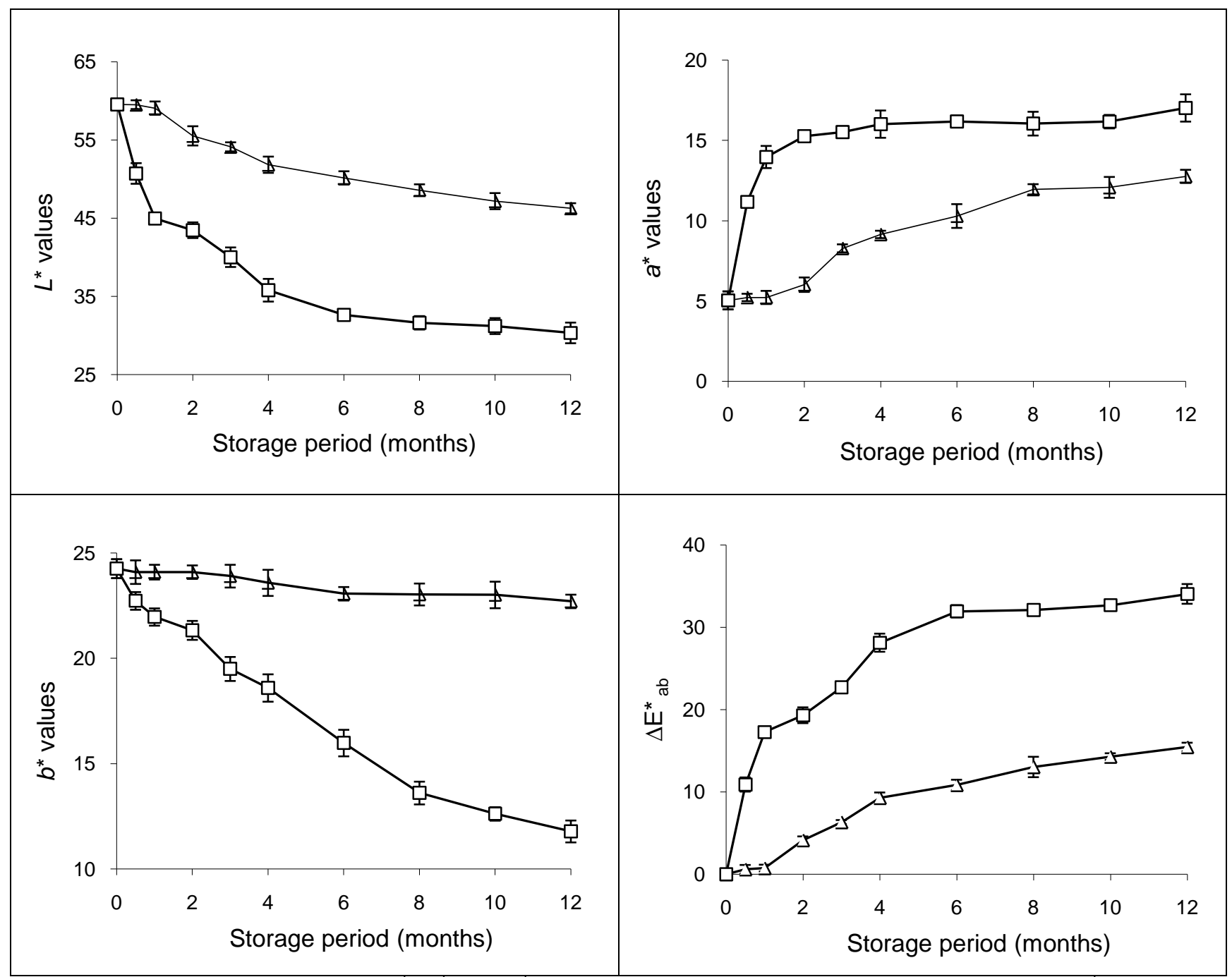

560 Fig. 4. Effect of light on $L^{*}, a^{*}$ and $b^{*}$ colour coordinates and total colour change $\left(\Delta \mathrm{E}^{*}{ }_{\mathrm{ab}}\right.$ 561 values) of faba bean seeds stored at $20^{\circ} \mathrm{C}$ for 12 months: in dark $(\Delta)$, under artificial light $(\square)$.

$562 \quad$ Error bars $= \pm$ s.d., $n=9$.

563

564 


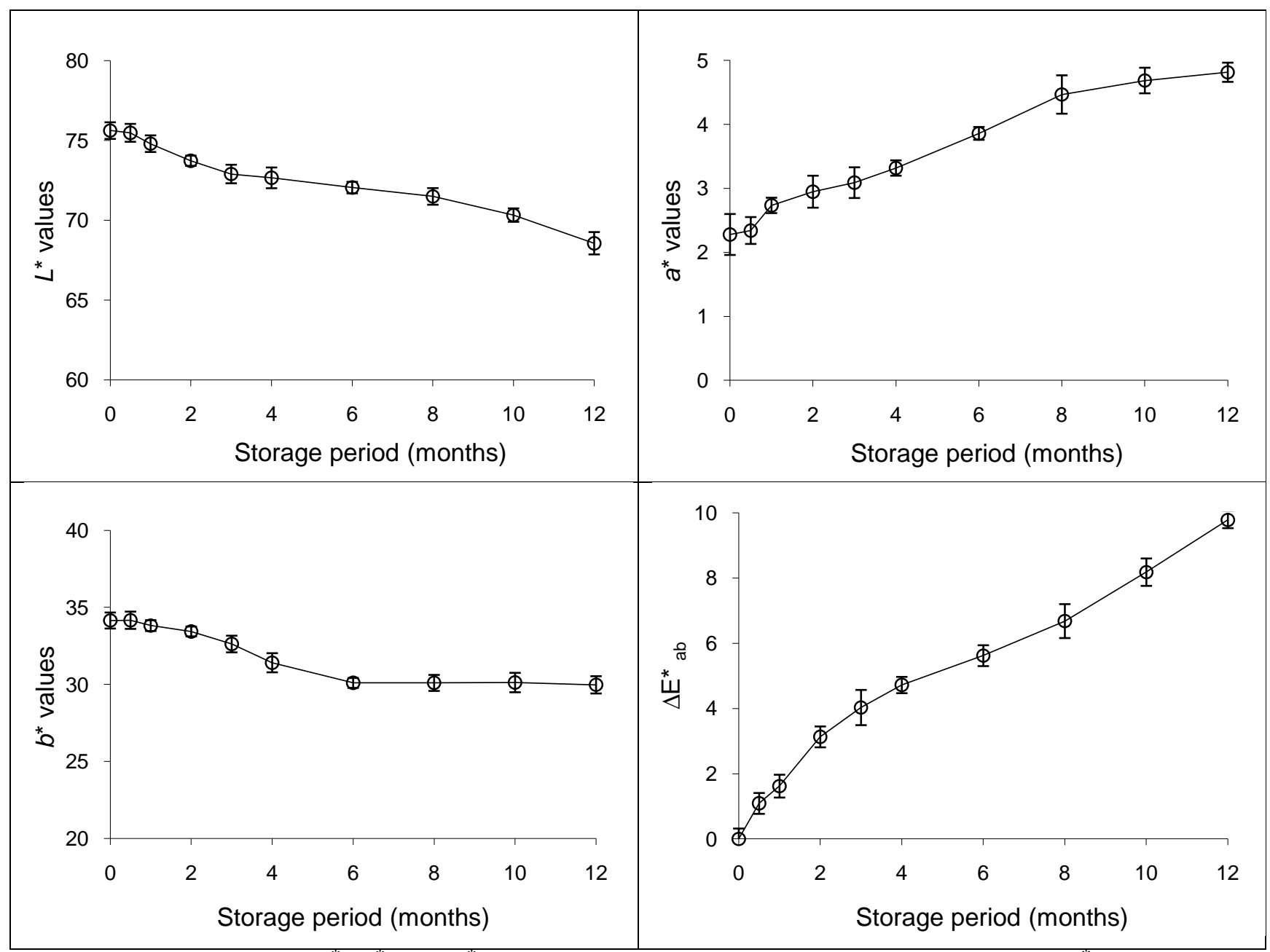

565 Fig. 5. Effect on $L^{*}, a^{*}$ and $b^{*}$ colour coordinates and total colour change $\left(E^{*}{ }_{\text {ab }}\right.$ values) of 566 faba bean cotyledons stored at $37^{\circ} \mathrm{C}$ for 12 months in dark (Error bars $= \pm$ s.d., $\mathrm{n}=9$ ). 